\title{
FINE STRUCTURE OF THE HAEMOCYTES OF THE INDIAN WHITE SHRIMP, FENNEROPENAEUS INDICUS (H. MILNE EDWARDS, 1837)
}

\author{
BY
}

\author{
P. LAXMILATHA ${ }^{1}$ ) and A. LAXMINARAYANA
}

Central Marine Fisheries Research Institute, P.O. Box 1603, Cochin 682 020, Kerala, India

\begin{abstract}
Three types of circulating haemocytes have been identified in the haemolymph of the Indian white shrimp, Fenneropenaeus indicus, by electron microscopy. The ultrastructure of an agranulocyte, a dense granulocyte, and a semi-dense granulocyte, are described. The possible presence of a fourth type of haemocyte, viz., the cyanocyte, is discussed. The ultrastructure of a special type of haemocyte found in the haemolymph of shrimps with a developing ovary is described.
\end{abstract}

\section{RÉSUMÉ}

Trois types d'hémocytes circulants ont été identifiés en microscopie électronique, dans l'hémolymphe de la crevette royale blanche Fenneropenaeus indicus. L'ultrastructure d'un agranulocyte, d'un granulocyte dense et celle d'un granulocyte semi-dense ont été décrites. La présence possible d'un quatrième type d'hémocyte, le cyanocyte, est discutée. L'ultrastructure d'un type particulier, supplémentaire, d'hémocyte trouvé dans l'hémolymphe de crevettes dont l'ovaire est en cours de développement, est décrite.

\section{INTRODUCTION}

Several important functions have been attributed to crustacean haemocytes. They have been reported to be involved in haemostasis (Bang, 1971; Wood et al., 1971; Bauchau \& De Brouwer, 1974), ecdysis (Bauchau \& Plaquet, 1973; Vacca \& Fingerman, 1975), and storage and transport of glycogen and other nutrients (Johnston et al., 1973) besides production of haemocyanin (Stang-Voss, 1971). The important role of haemocytes in defense mechanisms (phagocytosis, encapsulation, nodule formation, wound repair, and coagulation) has also been

\footnotetext{
1) Current address: Calicut Research Centre, Central Marine Fisheries Research Institute, West Hill P.O., Calicut 673 005, Kerala, India.
} 
recognized by several authors (Wood et al., 1971; Sinderman, 1971; Fontaine \& Lightner, 1974; Johnson \& Bodammer, 1975; Stewart, 1975; Johnson, 1976; Durliat, 1985; and Söderhäll \& Cerenius, 1992). Morphological studies on blood cells of Crustacea, however, are scarce, so that it is difficult to identify particular haemocyte types involved in defence reactions. Haemocytes of Crustacea have been generally classified into hyaline and granular cells based on subtle cytological criteria (Bauchau, 1981).

Ultrastructural studies on haemocytes of Astacus astacus (Linnaeus, 1758) (cf. Stang-Voss, 1971), Eriocheir sinensis (H. Milne Edwards, 1853) (cf. Bauchau \& De Brouwer, 1972), Carcinus maenas (Linnaeus, 1758) (cf. Johnston et al., 1973), Helleria brevicornis (Ebner, 1868) (cf. Hoarau, 1976), Litopenaeus setiferus (Linnaeus, 1758) (cf. Fontaine, 1978), Marsupenaeus japonicus (Bate, 1888), Penaeus monodon Fabricius, 1798, Macrobrachium rosenbergii (De Man, 1879), and Palaemon adspersus Rathke, 1837 (cf. Tsing et al., 1989), Sicyonia ingentis (Burkenroad, 1938) (cf. Martin et al., 1987), Homarus americanus H. Milne Edwards, 1837, Panulirus interruptus (Randall, 1840), Loxorhynchus grandis (Stimpson, 1857) (cf. Hose et al., 1990), and Squilla mantis (Linnaeus, 1758) (cf. Barraco \& Amirante, 1992) have aided in the classification as well as in the proper delineation of the types of haemocytes.

There are no published reports on the blood cells of the Indian white shrimp, Fenneropenaeus indicus (H. Milne Edwards, 1837), which is one of the prime species for aquaculture in Southeast Asia. This study was undertaken to provide new information on the cytology of haemocytes in order to support further investigations on functions attributed to the various types of haemocytes under pathological conditions.

This study describes the presence of three types of haemocytes based on their fine structure, and suggests that the maturation of blood cells in this species probably occurs along a single path of differentiation. The study also provides information for further investigations on the cytophysiological aspects and functions of the haemocytes.

\section{MATERIALS AND METHODS}

Fenneropenaeus indicus specimens were collected from the brackish water grow-out farms of the Central Institute of Brackish Water Aquaculture, Narakkal, as well as from offshore waters. The shrimps were transported to the laboratory at the Central Marine Fisheries Research Institute, Kochi, and maintained in 23-25\%o sea water in $1 \mathrm{~m}^{3}$ fibreglass tanks provided with continuous aeration. After 12-16 h acclimation, the haemolymph was collected. 
For light microscopy, haemolymph smears were prepared according to Mix \& Sparks (1980). Smears were thus air dried, fixed with methanol for 5 min., stained in Giemsa stain for 5 min., washed in double distilled water, and mounted in DPX. They were next observed under a compound microscope.

For use in electron microscopy, the procedure described by Martin \& Graves (1985) was adopted with some necessary modifications. Haemocytes were collected by inserting a 21-gauge needle attached to a $1 \mathrm{ml}$ syringe containing $0.4 \mathrm{ml}$ of fixative (3\% $0.1 \mathrm{M}$ glutaraldehyde solution, buffered to $\mathrm{pH} 7.3$ with $0.1 \mathrm{M}$ cacodylate containing sucrose) (Papathanassiou \& King, 1984) into the heart and withdrawing $100 \mu \mathrm{l}$ of haemolymph. The sample was transferred to a clean tube and mixed thoroughly.

The haemocytes were fixed for $12 \mathrm{~h}$ at $4^{\circ} \mathrm{C}$. Cell pellets obtained by centrifugation (1000 g for 5 minutes) were trimmed to $2 \mathrm{~mm}$ rectangular pieces, fixed again in chilled glutaraldehyde for $5 \mathrm{~h}$. These pellets were further washed several times in ice cold $0.1 \mathrm{M}$ cacodylate buffer to remove the excess aldehydes and then postfixed in freshly prepared $0.1 \%$ osmium tetroxide in cacodylate buffer solution for $2 \mathrm{~h}$ at $4^{\circ} \mathrm{C}$. This was followed by repeated washings in buffer solution at $15 \mathrm{~min}$. intervals. The fixed samples were stained in freshly prepared $0.5 \mathrm{M}$ aqueous uranyl acetate for $3 \mathrm{~h}$ at $4^{\circ} \mathrm{C}$, and excess stain removed by repeated washings with double distilled water. They were then dehydrated through graded alcohol solutions and embedded in Spurr resin. Semi-thin sections $(1 \mathrm{~mm})$ were stained with methylene blue-azure II / basic fuchsine (Humphrey \& Pittman, 1974) and observed under a light microscope. Ultra-thin sections (600-700 $\AA$ ) were mounted on copper or nickel grids, contrasted with $2 \%$ uranyl acetate, and screened under a Carl Zeiss transmission electron microscope at $80 \mathrm{kV}$.

\section{RESULTS}

The light microscopic study did not aid in the classification of the haemocytes, although three types of circulating haemocytes could be observed.

Based on ultrastructural study, three types of circulating haemocytes have been identified and classified, respectively, as agranulocyte (AG), dense granulocyte (DG), and semi-dense granulocyte (SG).

Agranulocyte. - Agranulocytes are the smallest type of haemocytes found in the haemolymph of Fenneropenaeus indicus. The average size of the haemocytes was $3.35 \times 4.76 \mu \mathrm{m}$. They are ovoid to spherical with the nuclear chromatin dispersed. The nucleus occupies much of the cell and is generally ovoid (fig. 1a). The nucleus/cytoplasm ratio is generally high. The nuclear envelope is smooth and cytoplasmic inclusions are few or absent (fig. 1b, c, d). Rough and smooth endoplasmic reticula were rarely seen in this type of haemocyte: the agranulocyte shows little signs of differentiation. 

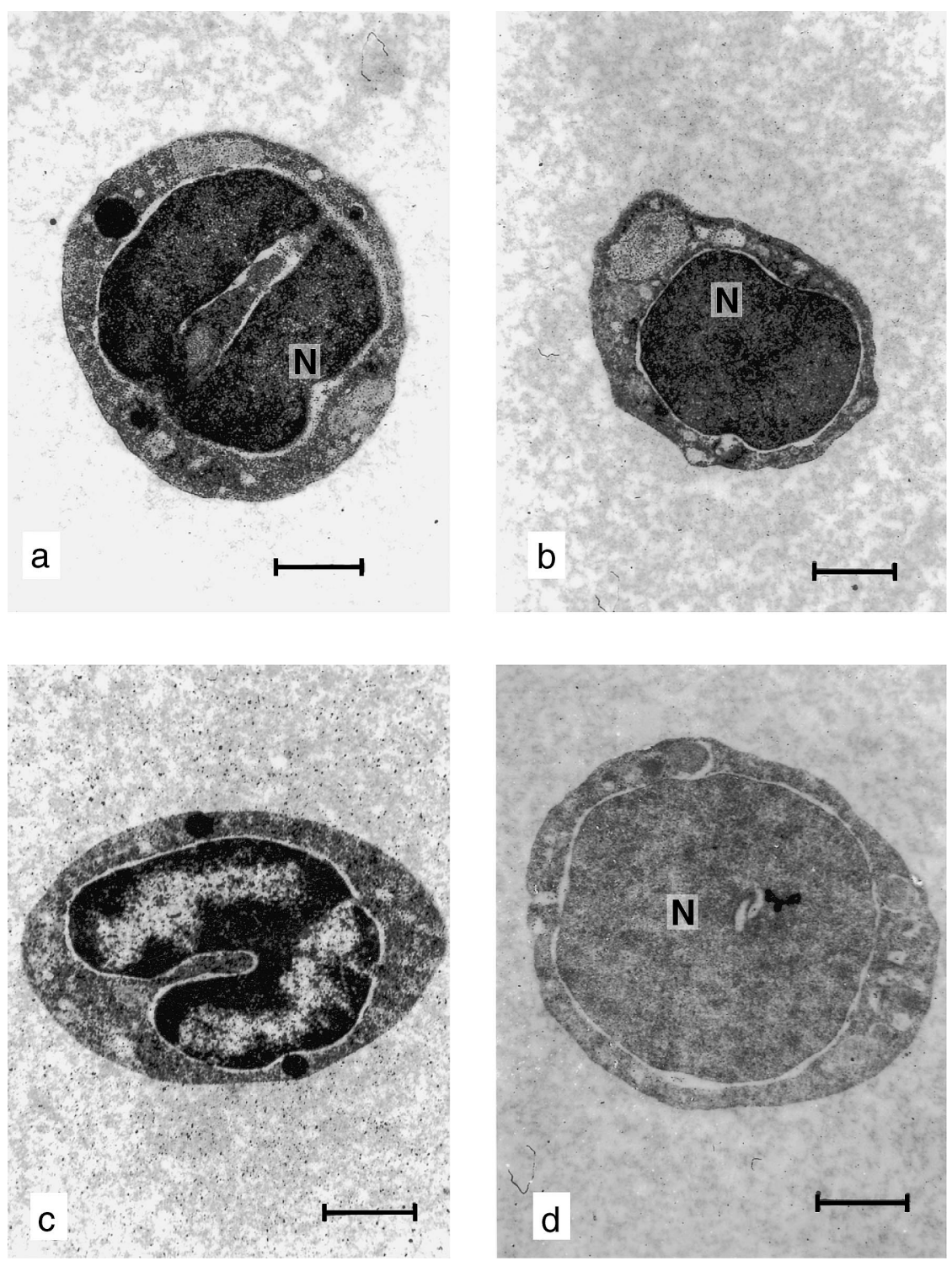

Fig. 1. Electron micrographs of haemocytes of Fenneropenaeus indicus (H. Milne Edwards, 1837): agranulocytes. a, Ovoid, with little cytoplasm around nucleus $(\mathrm{N})$; b, another agranulocyte, nucleus (N) occupies almost entire cytoplasm; c, note the horse-shoe shaped nucleus; d, note the large nucleus $(\mathrm{N})$. Scale bar $=1 \mu \mathrm{m}$.

Dense granulocyte. - These haemocytes are well differentiated and possess large numbers of dense granules (fig. 2a). They are generally ovoid, and larger than the other haemocytes: on the average, $4.72 \times 5.85 \mu \mathrm{m}$. The nucleus does not occupy the complete cytoplasmic space and a mass of dense heterochromatin 
is present close to the nuclear envelope. The nucleus may be variously shaped (fig. 2a). The most distinct feature of these haemocytes is the presence of thick or dense granules (fig. 2c, d). The granules vary in size from $0.1 \mu \mathrm{m}$ to $0.56 \mu \mathrm{m}$, and form the basis of identification of these haemocytes. In some cases, two types of granules are noticed within the cytoplasm: very dense granules $(\mathrm{G})$ and less dense granules (LG) (fig. 2c, d). The granules are membrane-bound and generally possess a homogeneous electron dense content, but sometimes exhibit an heterogeneous internal structure, made up of electron dense and electron lucent areas (fig. 2d). The cytoplasm of these haemocytes contains only few ribosomes and endoplasmic reticulum, and few vacuoles. The development of pseudopodia-like extensions on contact with any surface was also noticed (fig. 2a).

Semi-dense granulocyte. - These haemocytes constitute an intermediate type of blood cells (fig. 3a). They are ovoid or spindle-shaped, sometimes irregular, with an average size of $4.16 \times 7.18 \mu \mathrm{m}$. They are characterized by the presence of cytoplasmic granules, more numerous than those in the agranulocytes. These inclusions are usually much smaller than those found in the dense granulocytes, and measure approximately $0.043 \mu \mathrm{m}$. The nucleus in this type of haemocyte is also variously shaped (fig. 3b, c), but does not occupy the entire cellular volume. Regions of very dense heterochromatin are numerous and packed around the inside of the nuclear envelope. In a few cases, the nucleus is greatly reduced and the rough endoplasmic reticulum is more developed with narrow, elongated cristae compared to the reticulum of the dense granulocyte. Secretory vesicles with electron dense content and mitochondria were also noticed.

Cyanocyte. - An entirely different kind of haemocyte, the 'cyanocyte', was also observed. This cell type has a large central granule, and plenty of endoplasmic reticulum and mitochondria. Golgi bodies are also present (fig. 3d). Probably, this cell type does not circulate in the haemolymph but is found in the haematopoietic nodules.

Besides these circulating haemocytes, an entirely different type of haemocyte was observed in the haemolymph of females with a developing ovary. This haemocyte is at least three times larger than the other haemocytes, and is present in all stages of maturity as well as in the spent stage (figs. 4a, 5b). This haemocyte contains abundant glycogen granules in the cytoplasm. Several different types of lipoprotein granules are also present (figs. 4a, 5c). Highly electron dense granules of homogeneous as well as heterogeneous nature are observed. Mitochondria are abundant in this type of haemocyte (fig. 4b), and numerous vacuoles are also noticed (fig. 5a, b, c). Their probable functional significance is discussed below. 

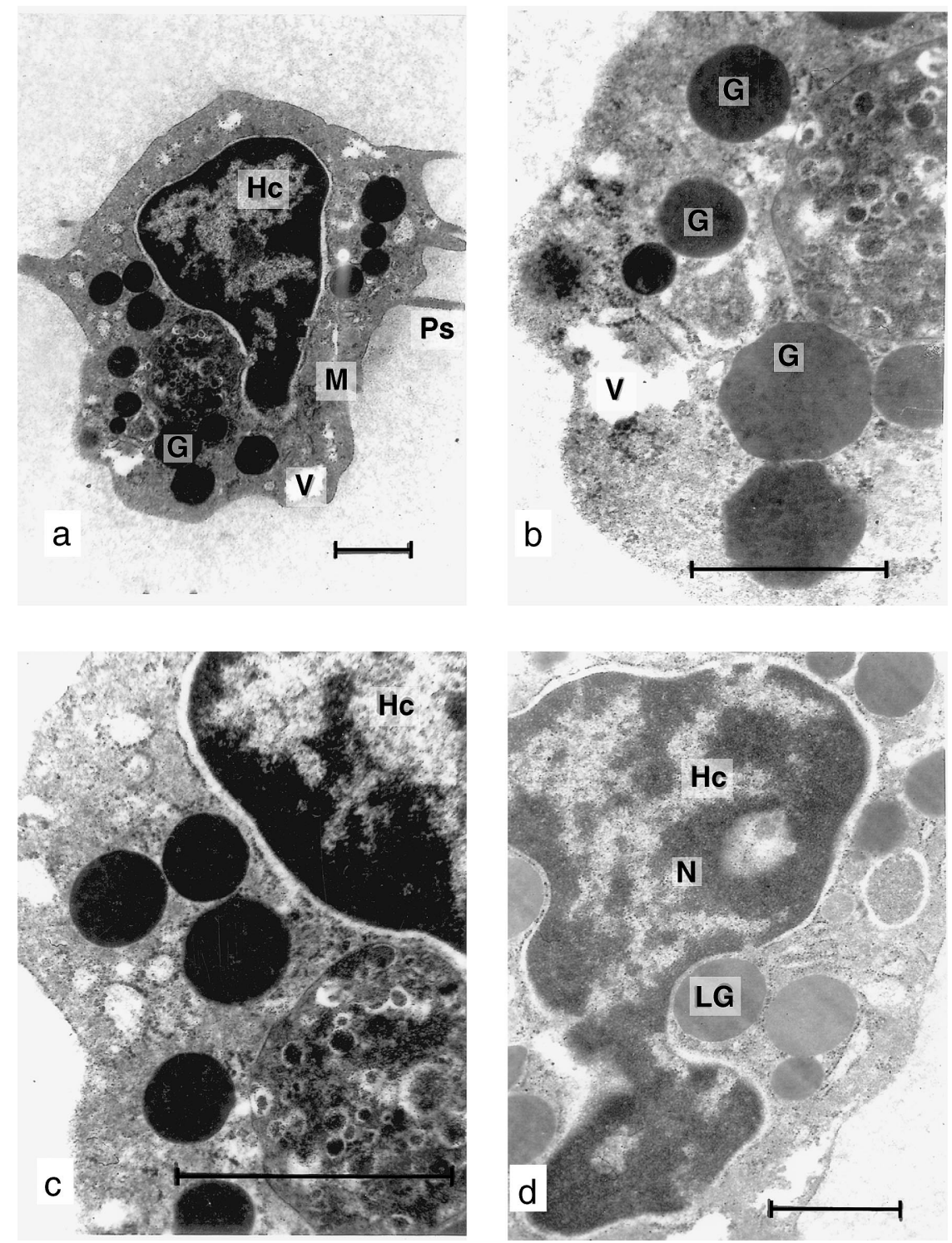

Fig. 2. Electron micrographs of haemocytes of Fenneropenaeus indicus (H. Milne Edwards, 1837): dense granulocytes. a, Note presense of dense granules (G), vacuoles (V), mitochondria (M), heterochromatin $(\mathrm{Hc})$ in the nucleus, and the pseudopodia-like extensions (Ps); b, lower half of the above granulocyte, note dense granules $(\mathrm{G})$ and vacuoles $(\mathrm{V})$; c, upper half of same granulocyte, note heterochromatin $(\mathrm{Hc})$ in the nucleus; $\mathrm{d}$, another dense granulocyte, note heterochromatin $(\mathrm{Hc})$ in the nucleus $(\mathrm{N})$ and the electron lucent (LG) granules. Scale bar $=1 \mu \mathrm{m}$. 

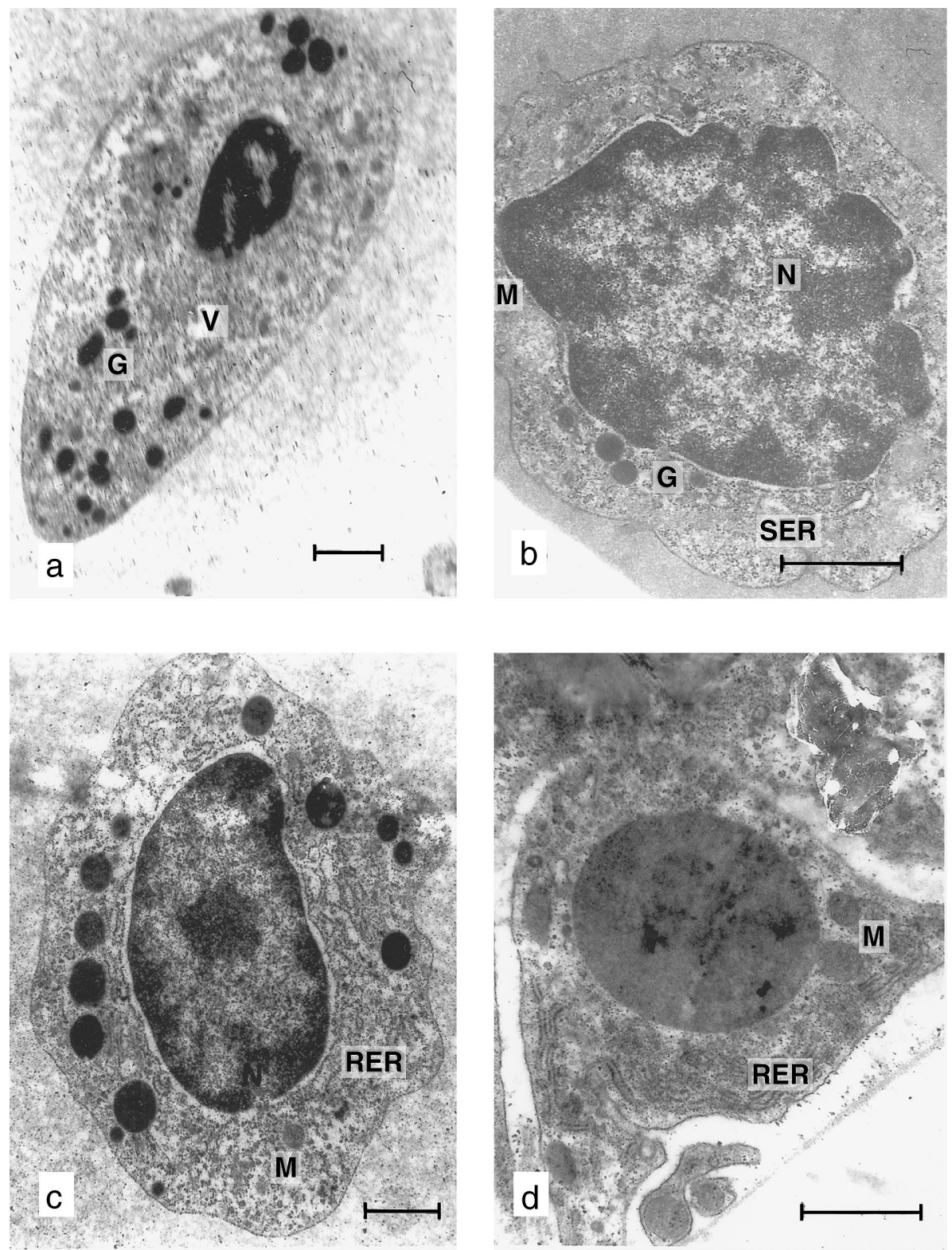

Fig. 3. Electron micrographs of haemocytes of Fenneropenaeus indicus (H. Milne Edwards, 1837): semi-dense granulocytes. a, Note presence of smaller granules (G) and vacuoles (V); b-c, other semi-dense granulocytes (transient forms), note mitochondria $(\mathrm{M})$, nucleus $(\mathrm{N})$, rough endoplasmic reticulum (RER), and smooth endoplasmic reticulum (SER); d, "cyanocyte", note the abundant rough endoplasmic reticulum (RER), mitochondria (M), and large central granular structure in centre. Scale bar $=1 \mu \mathrm{m}$. 

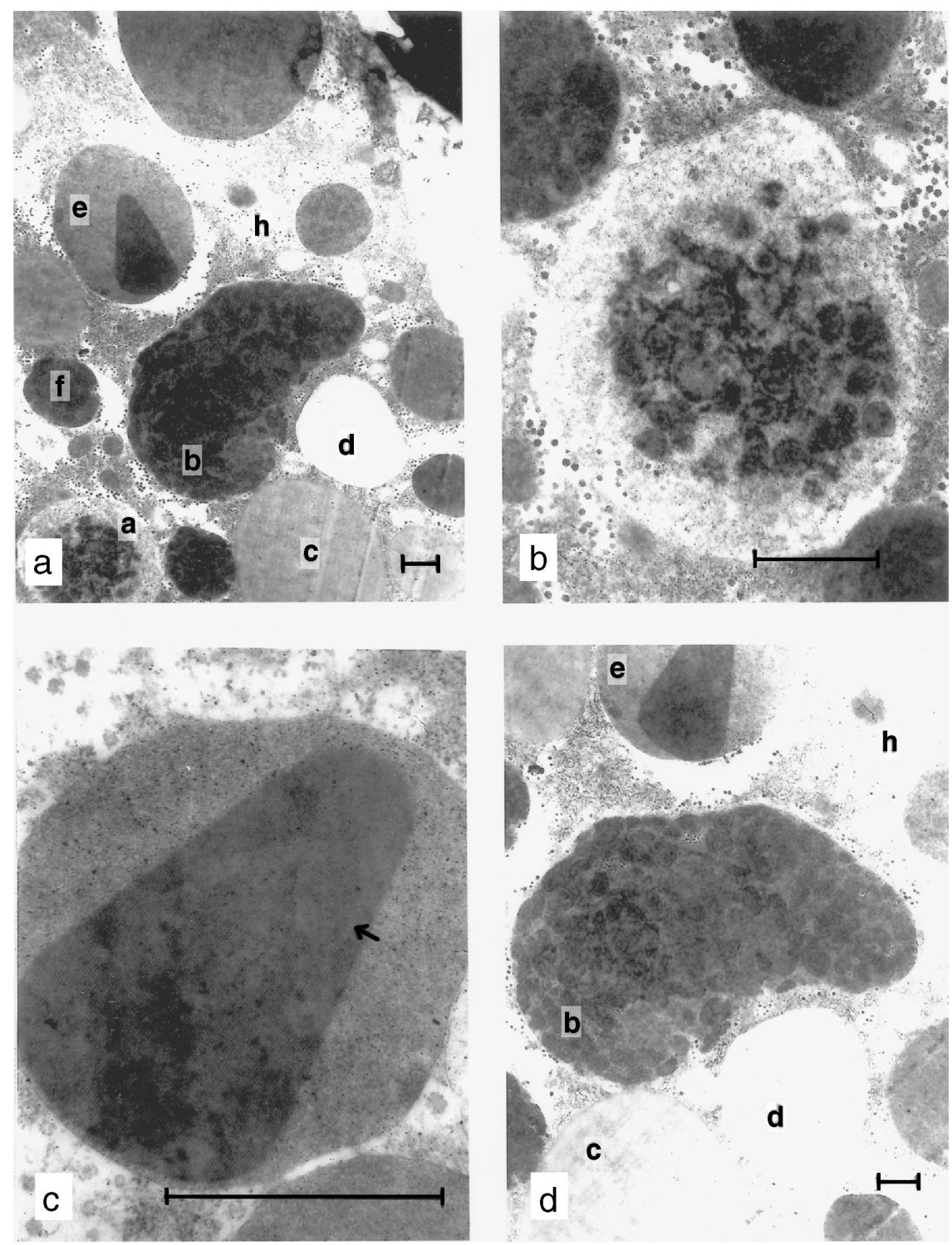

Fig. 4. Electron micrograph of haemocytes of Fenneropenaeus indicus (H. Milne Edwards, 1837): special type of haemocyte from female with mature ovary. a, Note presence of different types of inclusions within the cell (a, b, c, e, f, lipo-protein bodies; d, lipid body; h, glycogen granules); b, magnified view of inclusion "a" in the above cell, note presence of mitochondria inside; $c$, inclusion "e", note the ribbed nature of the crystalloid structure within (arrow); d, magnified view of inclusion "b", note presence of abundant mitochondria (c, d, e, h, correspond to fig. a). Scale bar $=1 \mu \mathrm{m}$. 

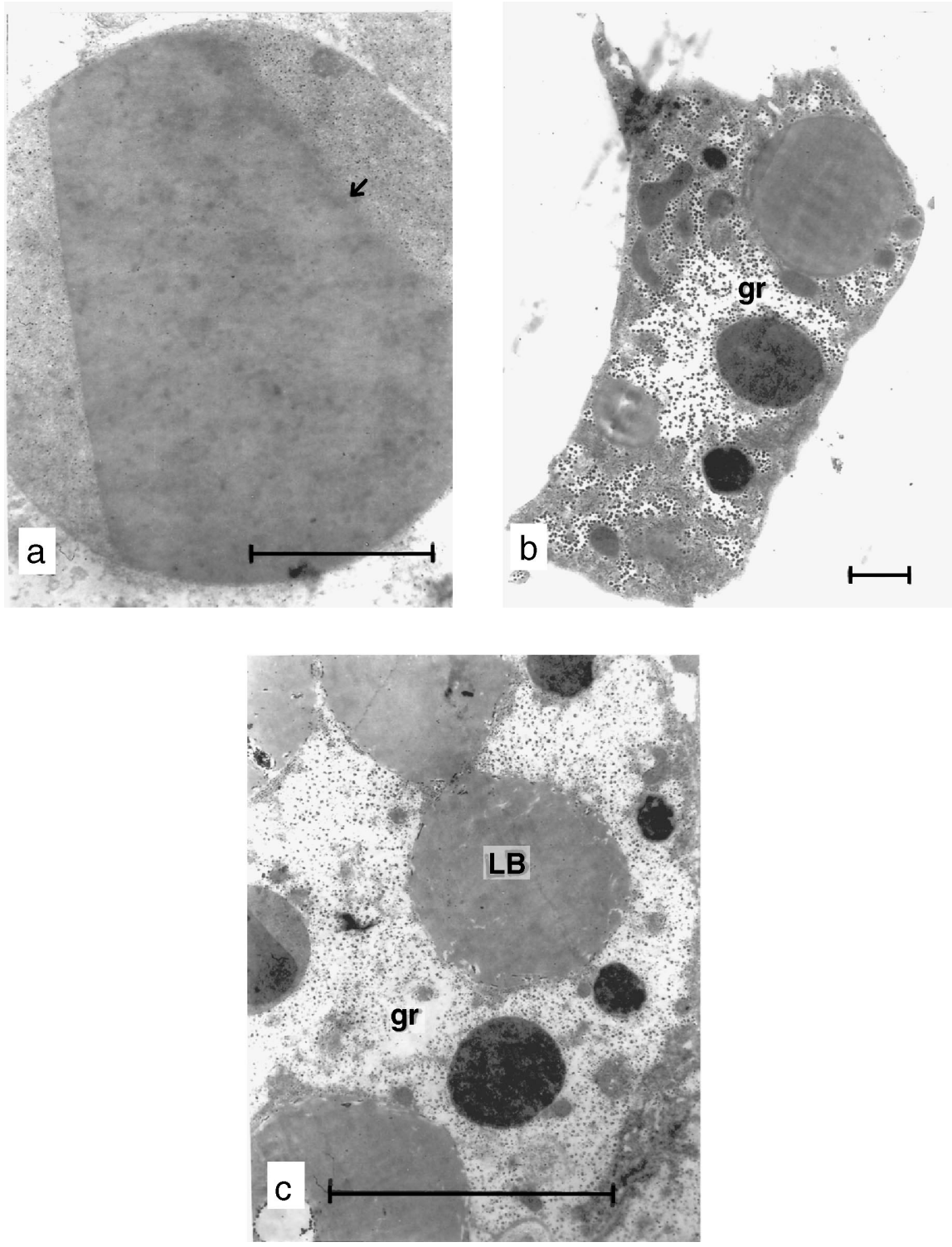

Fig. 5. Electron micrographs of haemocytes of Fenneropenaeus indicus (H. Milne Edwards, 1837): special type of haemocyte from female with mature ovary. a, Magnified view of inclusions, note the homogeneous nature of the crystalloid structure; $b$, note the abundant glycogen granules (small black dots, gr) and various types of inclusions; c, note the lipid bodies (LB), other protein inclusions, and abundant glycogen granules (gr). Scale bar $=1 \mu \mathrm{m}$. 


\section{DISCUSSION}

The haemocytes of Fenneropenaeus indicus are classified into three main types based on their ultrastructure, viz., an agranulocyte, a semi-dense granulocyte, and a dense granulocyte. The results obtained for $F$. indicus are in agreement with the general view that three circulating haemocyte populations exist in crustaceans (Bauchau, 1981), although various authors have adopted various terminologies as well as different classification schemes based on size, shape, staining characteristics, and the presence or absence of granules (George \& Nichols, 1948; Wood \& Visentin, 1967; Stang-Voss, 1971; Bauchau \& De Brouwer, 1972; Ravindranath, 1980; Cornick \& Stewart, 1978; Smith \& Ratcliff, 1978; Martin et al., 1987; Hose et al., 1990).

The three types of haemocytes found in Fenneropenaeus indicus can be compared with those reported from some other penaeids. Dall (1964) distinguished three types of blood cells in Metapenaeus mastersii (Haswell, 1878) based on light microscopy: the lymphocyte, the thigmocyte, and the large granulocyte. These were all based on cell shape and are comparable to, respectively, the agranulocyte, the semi-dense granulocyte, and the dense granulocyte in F. indicus. Based on fine structure, the blood cells of Litopenaeus setiferus were classified into agranular and granular haemocytes by Fontaine (1978). The granular haemocytes were further divided into two types: those that possess numerous large lipid inclusions, and those which display a definite texture or structure unlike that of the large lipid-like inclusions (Fontaine, 1978). These types are similar to the semi-dense and dense granulocytes in F. indicus. In F. indicus, the agranular cells that show little cellular differentiation appear similar to the undifferentiated cells of Marsupenaeus japonicus, Penaeus monodon, Macrobrachium rosenbergii, and Palaemon adspersus as described by Tsing et al. (1989) and Sequeira et al. (1995), based on flow cytometry. They termed them as "hyaline cells" since it was not possible to confirm that the hyaline or agranular cells do not possess any granular inclusions, which is also the case in Fenneropenaeus indicus.

The haemocytes of $F$. indicus are also similar to those described from crayfish and lobsters, although the terminology used varies widely. Based on cytochemical observations, Wood \& Visentin (1967) and Wood et al. (1971), described a hyaline cell, a small granulocyte, and a large granulocyte in Orconectes virilis (Hagen, 1870). Stang-Voss (1971) described only one cell type in Astacus astacus, the amoebocyte. However, three functional forms, the clotting cell, the phagocyte, and the granular haemocyte, were described (Stang-Voss, 1971). The clotting cell is characterized by a large number of granules containing internal tubular structures. This appears to be analogous to the granulocyte described in other forms. In the phagocytes, numerous granules are found, and in the granulocyte these occupy the 
complete cytoplasmic space. Sternshein \& Burton (1980), using light and electron microscopy, described the coagulocyte, the granulocyte, and the amoebocyte in Procambarus sp., which is comparable to the semi-dense granulocyte, dense granulocyte, and agranulocyte in Fenneropenaeus indicus. In Homarus, George \& Nichols (1948) and Toney (1958) described four types of blood cells while Hearing (1969) had identified three types based on ultrastucture in Homarus americanus: the eosinophil, the ovoid basophil, and the spindular basophil. All these cells contain large granules exhibiting acid-phosphatase activity, but are not characterized by their cytoplasm or other organelles. Cornick \& Stewart (1978) recognized four types of haemocyte in H. americanus based on size and refractile nature of the granules, the ratio of cytoplasm to nucleus, and Giemsa stain characteristics: two hyaline types (prohyalocytes) and two granulocytes (eosinophilic and chromophobic granulocytes). Cohen et al. (1983) also reported four cell types in $H$. americanus: granular elliptical cells with ovoid or tapering, pointed ends, and others, generally elliptical but with bulges or constrictions. Vranckx \& Durliat (1977) described the circulating cells in six species of lobsters (Jasus frontalis (H. Milne Edwards, 1837), J. paulensis (Heller, 1862), Panulirus regius De Brito Capello, 1864, Homarus gammarus (L., 1758) [as H. vulgaris] and Astacus leptodactylus Eschscholtz, 1823), three brachyurans (Cancer pagurus L., 1758, Maja squinado (Herbst, 1788), Xantho incisus (Leach, 1814)), and an anomuran (Galathea strigosa (L., 1767)), and stated that all circulating cells belong to a single lineage, the granulocyte.

The fourth type of haemocyte, namely, the "cyanocyte" observed by us in Fenneropenaeus indicus, could not be located in the general circulation. Such a haemocyte is described only from the cheliceran, Limulus polyphemus (L., 1758) (cf. Fahrenbach, 1970) and in Carcinus maenas (cf. Ghiretti-Magaldi et al., 1972, 1977). These cells are believed to synthesize and store haemocyanin as crystalline, cytoplasmic granules. The proteinaceous material is confined within membranebound granules and probably has a crystalline structure. As in the case of crabs, the cyanocyte in F. indicus probably stems from the haemoblasts and leaves the haematopoietic nodules (HPN) or haematopoietic organ, but does not enter into circulation. Instead, it must probably become attached to the connective tissue strands surrounding the ophthalmic artery, the dorso-lateral surface of the foregut, and the dorsal surface of the hepatopancreas, as also suggested for the penaeid ridgeback prawn, Sicyonia ingentis (Burkenroad, 1938) (cf. Martin et al., 1978). The haemocyanin may be released by the plasma membrane into the blood through a kind of holocrine secretion (Ghiretti-Magaldi et al., 1977).

The occurrence of the special kind of granulocyte as yet unnamed, which almost obliterates other haemocytes in the haemolymph of females with developing ovaries in F. indicus, generates great interest. Such a haemocyte has been reported 
only in Eriocheir sinensis (cf. Bauchau \& De Brouwer, 1972) and probably has great functional significance. It is probable that this haemocyte could have developed from the granulocyte. Their large size and the abundant granules of various kinds might well indicate that special requirements during ovarian development necessitate the transformation of the granulocytes into special carrier cells. These cells, apart from providing for the great energy demand (as justified by the presence of large mitochondria) during vitellogenesis and subsequent spawning, may also be transporting nutrients in the form of protein, lipids, and glycogen. The haemocytes seen in normal circulation are totally absent during all stages of ovarian development, thus indicating that possibly the agranular and semi-dense haemocytes also transform into these special carrier cells. This, again evokes questions on the actual lineage and mode of differentiation as well as on the specific functional role of individual haemocytes, necessitating detailed and specific studies.

The differentiation of crustacean haemocytes is still open for discussion. One group has proposed the evolution from hyaline to granular cells (Bodammer, 1978; Bauchau \& Mengeot, 1978; Benjamin \& James, 1987; Martin et al., 1987). This idea was first proposed by Cuénot (1893). Another group has proposed the reverse order of evolution, starting from granular and leading to hyaline haemocytes (Vranckx \& Durliat, 1977). Sternshein \& Burton (1980) suggested yet another hypothesis, namely, that in crayfish the observed haemocyte types are functional or developmental stages of one single cell type. In Fenneropenaeus indicus, some apparently hyaline cells do possess a few small granules, indicating possible differentiation of the agranular to the semi-dense and further on to the dense granular stage. Since the shape of the granules within the cells does not vary much, this adds credence to the theory proposed by Bauchau \& Mengeot (1978). Yet, the total lack of these haemocytes during vitellogenesis, as well as the occurrence of the special kind of heavy granule-packed haemocytes in the haemolymph of females with mature ovaries, would suggest that probably only one haemocyte type exists, and all others are functional or developmental stages of this haemocyte type as proposed by Sternshein \& Burton (1980). Elucidation of the exact lineage and maturation sequence of haemocyte types will require autoradiographic studies in order to arrive at a definite conclusion.

\section{ACKNOWLEDGEMENTS}

This study formed part of the Ph. D. research work of the first author (PL), for which a Senior Research Fellowship was awarded by the Indian Council of Agricultural Research, New Delhi. The facilities provided by the authorities of the Central Marine Fisheries Research Institute, Kochi, are gratefully acknowledged. The 
first author also expresses her profound gratitude to Dr. J. J. Solomon, Head, Plant Pathology Laboratory, Central Plantation Crops Research Institute, Regional Station, Kayamkulam, Kerala, for assistance in carrying out the ultrastructural study.

\section{REFERENCES}

BANG, F. B., 1971. A factor in crab amoebocytes, which stimulates in vitro clotting of crab blood. Journ. Invertebr. Pathol., 18: 280-283.

Barraco, M. A. \& G. A. Amirante, 1992. Histological and cytochemical studies on the hemocytes of Squilla mantis (Stomatopoda). Journ. Crust. Biol., 12 (3): 372-382.

Bauchau, A. B., 1981. Crustaceans. In: N. A. RATClifF \& A. F. RowleX (eds.), Invertebrate blood cells, 2: 386-420. (Academic Press, New York).

BAuchau, A. G. \& M. B. DE BRouwer, 1972. Ultrastructure des haemocytes d'Eriocheir sinensis (Crustacé, Décapode, Brachyoure). Journ. Microsc., 15: 171-180.

—— \& — - 1974. Étude ultrastructurale de la coagulation de l'haemolymphe chez les Crustacés. Journ. Microsc., 19: 37-46.

Bauchau, A. G. \& J. C. Mengeot, 1978. Structure et fonction des haemocytes chez les Crustacés. Arch. Zool. exp. gén., 119: 227-248.

Bauchau, A. G. \& J. C. Plaquet, 1973. Variation des nombres des haemocytes chez les Crustacés brachyures. Crustaceana, 24: 215-223.

BENJAMIN, L. R. \& B. L. JAMES, 1987. Light and electron microscopy of the haemocytes of Ligia oceanica (L.) (Crustacea, Isopoda). Journ. Invertebr. Pathol., 49: 19-25.

BodAMmer, J. E., 1978. Cytogical observations on the blood and hemopoietic tissue in the crab, Callinectes sapidus. I. Fine structure of haemocytes from intermoult animals. Cell Tiss. Res., 187: 79-86.

Cohen, W. D., I. Nemhauser \& M. F. Cohen, 1983. Marginal bands of lobster blood cells: disappearance associated with changes in cell morphology. Biol. Bull., Woods Hole, 164: 5060.

CORNICK, J. W. \& J. E. STEWART, 1978. Lobster (Homarus americanus) hemocytes: classification, differential counts and associated agglutinin activity. Journ. Invertebr. Pathol., 31: 194-203.

Cú́not, L., 1895. Études physiologiques sur les Crustacés Décapodes. Arch. Biol., 13: 245-303.

DALL, W., 1964. Studies on the physiology of a shrimp, Metapenaeus mastersii (Haswell) (Crustacea, Decapoda, Penaeidae). I. Blood constituents. Australian Journ. mar. freshw. Res., 15: $145-161$.

- - 1974. Indices of nutritional state in the western rock lobster Panulirus longipes (Milne Edwards). I. Blood and tissue constituents and water content. Journ. exp. mar. Biol. Ecol., 16: $167-180$.

Durliat, M., 1985. Clotting processes in Crustacea, Decapoda. Biol. Rev., 60: 473-498.

FAHRENBACH, W. H., 1970. The cyanoblast: haemocyanin formation in Limulus polyphemus. Journ. Cell Biol., 44: 445-453.

FontAIne, C. T., 1978. The circulating haemocytes of the white shrimp, Penaeus setiferus. Origin, abundance, morphology and function: 1-53. (M.Sc. Thesis, Texas A \& M University, Galveston, Texas).

Fontaine, C. T. \& D. V. Lightner, 1975. Cellular responses to injury in penaeid shrimp. Mar. Fish. Rev., 37: 4-10.

George, W. C. \& J. Nichols, 1948. A study of the blood of some Crustacea. Journ. Morphol., 83: 425-443.

Ghiretti-MagAldi, A., C. Milanesi \& B. Salvato, 1972. Ricerche sulle emocianne, xxiii. I cianoblasti i cianociti nei tessuti di Carcinus maenas. Experientia, 29: 1265-1267. 
Ghiretti-Magaldi, A., C. Milanesi \& G. Tognon, 1977. Hemopoiesis in Crustacea, Decapoda: origin and evolution of hemocytes and cyanocytes of Carcinus maenas. Cell. Differ., 6: $167-186$.

HoARAU, F., 1976. Ultrastructure des hemocytes de l'oniscoide Helleria brevicornis Ebner (Crustacé Isopode). Journ. microsc. Biol. Cell, 27: 47-52.

Hose, J. E., G. G. Martin \& A. S. Gerard, 1990. A decapod haemocyte classification scheme integrating morphology, cytochemistry and function. Biol. Bull., Woods Hole, 178: 33-45.

Humphrey, C. D. \& F. E. PitTman, 1974. Methylene blue-Azure II and basic fuchsine staining for semithin sections. Stain Technol., 49: 9-14.

Johnston, M. A., H. Y. Elder \& P. S. DAVIES, 1973. Cytology of Carcinus haemocytes and their function in carbohydrate metabolism. Comp. Biochem. Physiol., (A) 46: 569-581.

Johnson, P. T., 1976. Bacterial infection in the blue crab, Callinectes sapidus: course of infection and histopathology. Journ. Invertebr. Pathol., 28: 25-26.

Johnson, P. T. \& J. E. BoDAMMER, 1975. A disease of the blue crab, Callinectes sapidus of possible viral etiology. Journ. Invertebr. Pathol., 26: 141-143.

Martin, G. G. \& B. L. GraVes, 1985. Fine structure and classification of shrimp haemocytes. Journ. Morphol., 185: 339-348.

MARTIN. G. G., J. E. Hose \& J. J. KIM, 1987. Structure of haematopoietic nodules in the ridgeback prawn Sicyonia ingentis: light and electron microscopic observations. Journ. Morphol., 192: 193-204.

Mix, M. C. \& A. L. Sparks, 1980. Haemocyte classification and differential counts in Cancer magister. Journ. Invertebr. Pathol., 35: 134-143.

PAPATHANASSIOU, E. \& P. E. KING, 1984. Ultrastructural studies on gametogenesis of the prawn, Palaemon serratus (Pennant). I. Oogenesis. Acta Zool., 65 (1): 17-31.

RAVINDRANATH, M. H., 1980. Haemocytes in haemolymph coagulation of arthropods. Biol. Rev., 55: $139-170$.

Sequeira, T., M. Vilanova, A. Lobo-da-Cunha, L. Baldaia \& M. Arala-Chaves, 1996. Flow cytometric analysis of molt-related changes in haemocyte type in male and female Penaeus japonicus. Biol. Bull., Woods Hole, 189: 376-380.

SindERMAN, C. J., 1971. Internal defences of Crustacea: a review. Fish. Bull., U.S., 69 (3): $455-$ 489.

Smith, J. \& N. A. RATClifF, 1978. Host defense reactions of the shore crab Carcinus maenas (L.) in vitro. Journ. mar. biol. Assoc., U.K., 58: 367-379.

Söderhäll, K. \& L. CERENIUS, 1992. Crustacean immunity. Ann. Rev. Fish. Disease, 2: 3-23.

STANG-Voss, C., 1971. Studies on the ultrastructure of invertebrate haemocytes. V. On the haemocytes of Astacus astacus (L.) (Crustacea). Zeitschr. Zellforsch., 122: 69-75.

SternsheIN, D. J. \& P. R. BURTON, 1980. Light microscopic and electron microscopic studies of crayfish haemocytes. Journ. Morphol., 165: 67-84.

ToneY, M. E., 1958. Morphology of the blood cells of some Crustacea. Growth, 22: 35-50.

TSING, A., J. M. ARCIER \& M. BREHELIN, 1989. Haemocytes of penaeid and palaemonid shrimps: morphology, cytochemistry and haemograms. Journ. Invertebr. Pathol., 53: 64-77.

VRANCKX, R. \& M. DURliat, 1977. Études des haemocytes circulants de quelques Crustacés Décapodes. Corrélations entre polymorphisme et mode de prélèvement. C. R. Acad. Sci., Paris, (D) 285: 1045-1047.

Wood, P. J., J. Podlewski \& T. E. Shenk, 1971. Cytochemical observation of haemolymph cells during coagulation in the crayfish, Orconectes virilis. Journ. Morphol., 134: 479-488.

WooD, P. J. \& L. P. VISENTIN, 1967. Histological and histochemical observations of the haemolymph cells in the crayfish, Orconectes virilis. Journ. Morphol., 123: 559-568.

First received 23 October 2003.

Final version accepted 11 May 2004. 